Article

\title{
Diverse Components of Resistance to Fusarium verticillioides Infection and Fumonisin Contamination in Four Maize Recombinant Inbred Families
}

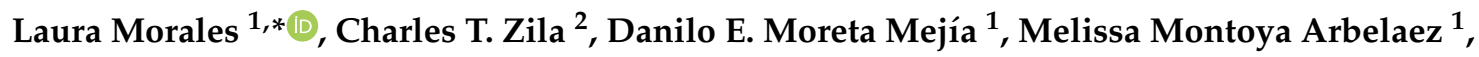 \\ Peter J. Balint-Kurti ${ }^{3,4}{ }^{(D)}$, James B. Holland ${ }^{2,4}$ and Rebecca J. Nelson ${ }^{1, *}$ \\ 1 School of Integrative Plant Science, Cornell University, Ithaca, NY 14853, USA; \\ dem324@cornell.edu (D.E.M.M.); mmontoyaa@unal.edu.co (M.M.A.) \\ 2 Department of Crop and Soil Sciences, North Carolina State University, Raleigh, NC 27695, USA; \\ ctzila@ncsu.edu (C.T.Z.); james_holland@ncsu.edu (J.B.H.) \\ 3 Department of Entomology and Plant Pathology, North Carolina State University, Raleigh, NC 27695, USA; \\ pjbalint@ncsu.edu \\ 4 Plant Science Research Unit, United States Department of Agriculture-Agricultural Research Service, \\ Raleigh, NC 27695, USA \\ * Correspondence: lm596@cornell.edu (L.M.); rjn7@cornell.edu (R.J.N.); \\ Tel.: +1-607-237-2706 (L.M.); +1-607-254-7475 (R.J.N.)
}

Received: 29 November 2018; Accepted: 22 January 2019; Published: 1 February 2019

check for updates

\begin{abstract}
The fungus Fusarium verticillioides can infect maize ears, causing Fusarium ear rot (FER) and contaminating the grain with fumonisins (FUM), which are harmful to humans and animals. Breeding for resistance to FER and FUM and post-harvest sorting of grain are two strategies for reducing FUM in the food system. Kernel and cob tissues have been previously associated with differential FER and FUM. Four recombinant inbred line families from the maize nested associated mapping population were grown and inoculated with F. verticillioides across four environments, and we evaluated the kernels for external and internal infection severity as well as FUM contamination. We also employed publicly available phenotypes on innate ear morphology to explore genetic relationships between ear architecture and resistance to FER and FUM. The four families revealed wide variation in external symptomatology at the phenotypic level. Kernel bulk density under inoculation was an accurate indicator of FUM levels. Genotypes with lower kernel density-under both inoculated and uninoculated conditions-and larger cobs were more susceptible to infection and FUM contamination. Quantitative trait locus (QTL) intervals could be classified as putatively resistance-specific and putatively shared for ear and resistance traits. Both types of QTL mapped in this study had substantial overlap with previously reported loci for resistance to FER and FUM. Ear morphology may be a component of resistance to F. verticillioides infection and FUM accumulation.
\end{abstract}

Keywords: maize; mycotoxins; fumonisin; disease resistance; morphology

Key Contribution: To our knowledge, this is the first study to document the colocalization of genetic loci underlying ear morphology and resistance to $F$. verticillioides infection and fumonisin contamination. We also demonstrate the value of kernel bulk density as a low-cost proxy for fumonisin levels in maize grain. 


\section{Introduction}

In maize (Zea mays L), the fungus Fusarium verticillioides causes Fusarium ear rot (FER) and contaminates grain with fumonisins (FUM), a family of mycotoxins produced by Fusarium spp. [1]. FER and FUM contamination can reduce yields and grain marketability [2]. FUM exposure has also been linked to adverse health outcomes in humans and domesticated animals [3-8]. The combination of the role of maize as a staple crop, conducive environmental conditions for F. verticillioides infection (FVI), and limited regulation of mycotoxins in food systems has led to high FUM exposure in the developing world [4-6,9-11].

Pre- and post-harvest management can reduce FUM levels in food systems. Agronomic practices, such as crop residue removal and soil nutrient management, have been associated with reduced risk of FUM contamination in maize [12,13]. Breeding for resistance to FVI and FUM contamination in maize varieties is a more long-term pre-harvest approach [14]. Post-harvest strategies include visual and optical grain sorting $[15,16]$ and thermochemical treatments $[17,18]$.

Genetic resistance to FER and FUM contamination in maize is moderately to highly heritable and quantitatively controlled, making breeding for durable resistance feasible [19-22]. Both morphological and biochemical characteristics have been shown to contribute genetic resistance. Biochemical signatures associated with differential FVI and FUM levels include lipid profiles [23] and biosynthesis of oxylipins and plant hormones, such as ethylene, abscisic acid, salicylic acid, and jasmonic acid [24,25]. The phenylpropanoid pathway, which is involved in lignin biosynthesis, has also been implicated in resistance to FVI and FUM contamination, although it is unknown whether phenylpropanoids play a passive role in resistance via pericarp hardening or whether they have an active inhibitory effect on F. verticillioides [24,26,27].

Cob and kernel morphological traits have been linked to differential FVI severity and FUM contamination. FVI and FUM levels have been negatively associated with kernel traits related to density and hardness [26,28-33], and kernel bulk density (also known as test weight) under F. verticillioides inoculation has been shown to be genetically correlated with FER and FUM [33,34]. Resistance to FUM contamination could therefore hypothetically be accomplished via indirect selection for increased kernel bulk density [35]. Cob morphology, an important component of yield [36], has also been shown to be genetically correlated with FER and FUM [33]. Variation in external symptomatology of kernels infected with $F$. verticillioides has been associated with differential FUM accumulation [33,37-39], suggesting that qualitative measures of kernel symptom severity are important components of resistance.

Understanding the variation in and the role of the maize host genetics in symptomatology of kernels under F. verticillioides inoculation could potentially reveal diverse modes of pathogenesis and/or host resistance. The maize nested association mapping (NAM) population, composed of 25 recombinant inbred line (RIL) families derived from 25 diverse inbred lines crossed to one recurrent inbred parent (B73), is a powerful tool for dissecting the genetic architecture of quantitatively inherited traits [40]. Here we employed quantitative, qualitative, external, and internal indicators of FVI severity as well as publicly available data on ear architecture phenotypes [41,42] to dissect the genetic mechanisms underlying FVI-specific and ear-mediated resistance to FVI and FUM accumulation in four NAM RIL families.

\section{Results}

\subsection{Symptomatology Varies among Families}

Four NAM RIL families $($ B73 $\times$ CML333, B73 × CML52, B73 × CML69, and B73 × NC358) were grown in an augmented incomplete block design across four environments. We inoculated the ears with toothpicks coated in F. verticillioides spores, a method that has previously been shown to reveal cob and kernel resistance mechanisms [33]. We evaluated the inoculated ears for external and internal indicators of disease severity. External phenotypes included FER (proportion of visibly infected kernels) and a symptom typology to account for qualitative variation in FER. Internal measures were 
grain FUM concentration, grain toxin load per visibly infected area (FUM:FER), and kernel bulk density $\left(\mathrm{BDEN}_{\text {inoc }}\right)$. As demonstrated by ANOVA, all four quantitative FVI indicators (FER, FUM,

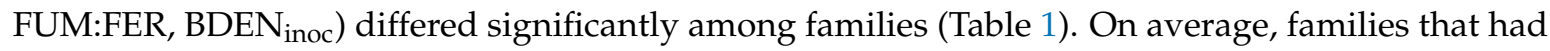
higher $B B_{\text {inoc }}$ tended to have lower FER, FUM and FUM:FER (Table 1). The B73 × CML333 family was unique in that it had high FER scores but had the least severe internal disease severity (highest BDEN $_{\text {inoc }}$ and low FUM and FUM:FER) (Table 1).

The composition of symptom types significantly differed among families, as determined by a $\chi^{2}$ test comparing the proportions of plots exhibiting asymptomatic, blush, starburst, purple, moldy, or multiple symptom types across three environments among the four RIL families $\left(\chi^{2}=265, p<0.0001\right)$. Across families, the majority of plots (57\% to 75\%) exhibited the starburst or purple symptom types (Figure 1). The B73 $\times$ CML333 family had the greatest proportion of plots exhibiting the blush type $(22 \%)$ (Figure 1). The B73 $\times$ CML52 family had the largest proportion of asymptomatic (20\%) and starburst (44\%) plots (Figure 1). The proportion of purple plots was greatest in the B73 × CML69 (35\%) and B73 $\times$ NC358 (40\%) families (Figure 1). Approximately 9\% of plots exhibited multiple symptoms in all families (Figure 1).

Table 1. Comparison of kernel bulk density $\left(\mathrm{BDEN}_{\text {inoc }}\right)$, Fusarium ear rot (FER), fumonisin concentration (FUM), and the ratio of FUM to FER (FUM:FER) under Fusarium verticillioides inoculation among four nested association mapping (NAM) recombinant inbred line (RIL) families and among

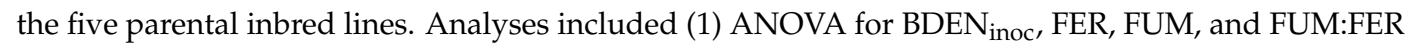
vs. family or parent, and (2) pairwise $t$-tests comparing BDEN $_{\text {inoc }}$, FER, FUM, and FUM:FER between families or parents. FER was evaluated across four environments, FUM and FUM:FER across three environments, and $\mathrm{BDEN}_{\text {inoc }}$ across two environments.

\begin{tabular}{|c|c|c|c|c|c|}
\hline Family & RILs (N/env) & $\begin{array}{c}\text { BDEN }_{\text {inoc }}^{* * *} \\
\left(\mathrm{~g} \mathrm{~mL}^{-1}\right)\end{array}$ & $\begin{array}{c}\text { FER *** } \\
(\%)\end{array}$ & $\begin{array}{l}\text { FUM } * * * \\
(p p m)\end{array}$ & $\begin{array}{c}\text { FUM:FER *** } \\
\left(\mathrm{ppm}^{-1}\right)\end{array}$ \\
\hline B73 $\times$ CML333 & 186 & $0.737 \pm 0.003 \mathrm{~A}$ & $43.04 \pm 1.27 \mathrm{~A}$ & $24.24 \pm 5.32 \mathrm{~B}$ & $0.51 \pm 0.10 \mathrm{C}$ \\
\hline B73 × CML52 & 177 & $0.720 \pm 0.004 \mathrm{~B}$ & $34.41 \pm 1.05 \mathrm{~B}$ & $11.77 \pm 2.39 \mathrm{~B}$ & $0.60 \pm 0.08 \mathrm{~B}$ \\
\hline B73 × CML69 & 186 & $0.712 \pm 0.003 \mathrm{~B}$ & $40.04 \pm 1.23 \mathrm{~A}$ & $31.28 \pm 5.05 \mathrm{~A}$ & $1.00 \pm 0.13 \mathrm{AB}$ \\
\hline $\mathrm{B} 73 \times \mathrm{NC} 358$ & 179 & $0.683 \pm 0.004 \mathrm{C}$ & $43.27 \pm 1.20 \mathrm{~A}$ & $32.62 \pm 4.21 \mathrm{~A}$ & $1.19 \pm 0.23 \mathrm{~A}$ \\
\hline Parent & Plots (N/env) & $\begin{array}{l}\text { BDEN }_{\text {inoc }}{ }^{* * *} \\
\left(\mathrm{~g} \mathrm{~mL}^{-1}\right)\end{array}$ & $\begin{array}{c}\text { FER *** } \\
(\%)\end{array}$ & $\begin{array}{l}\text { FUM *** } \\
(\mathrm{ppm})\end{array}$ & $\begin{array}{c}\text { FUM:FER } \\
\left(\text { ppm }^{-1}\right)\end{array}$ \\
\hline B73 & 39 & $0.650 \pm 0.005 \mathrm{C}$ & $47.83 \pm 2.26 \mathrm{~A}$ & $72.93 \pm 14.41 \mathrm{~A}$ & $2.36 \pm 0.64 \mathrm{~A}$ \\
\hline CML333 & 11 & $0.770 \pm 0.008 \mathrm{~A}$ & $26.65 \pm 3.37 \mathrm{~B}$ & $7.09 \pm 2.82 \mathrm{~B}$ & $0.47 \pm 0.18 \mathrm{~B}$ \\
\hline CML52 & 11 & $0.714 \pm 0.020 \mathrm{~B}$ & $13.39 \pm 3.17 \mathrm{C}$ & $3.18 \pm 0.78 \mathrm{~B}$ & $0.76 \pm 0.26 \mathrm{AB}$ \\
\hline CML69 & 11 & $0.745 \pm 0.004 \mathrm{AB}$ & $25.42 \pm 5.89 \mathrm{~B}$ & $6.69 \pm 2.08 \mathrm{~B}$ & $0.48 \pm 0.20 \mathrm{AB}$ \\
\hline NC358 & 11 & $0.766 \pm 0.007 \mathrm{~A}$ & $26.18 \pm 3.67 \mathrm{~B}$ & $16.14 \pm 7.36 \mathrm{~B}$ & $0.63 \pm 0.25 \mathrm{AB}$ \\
\hline
\end{tabular}

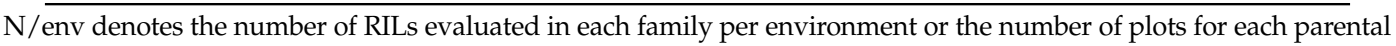
line per environment. Raw means and standard errors (SE) are reported, but ANOVA and pairwise $t$-tests were conducted on Box-Cox transformed data. Groups not connected by the same letter within each column are significantly different (pairwise two-tailed $t$-tests, $p<0.05$ ). ${ }^{* * *} p<0.0001$ for ANOVA of trait in column header vs. family.

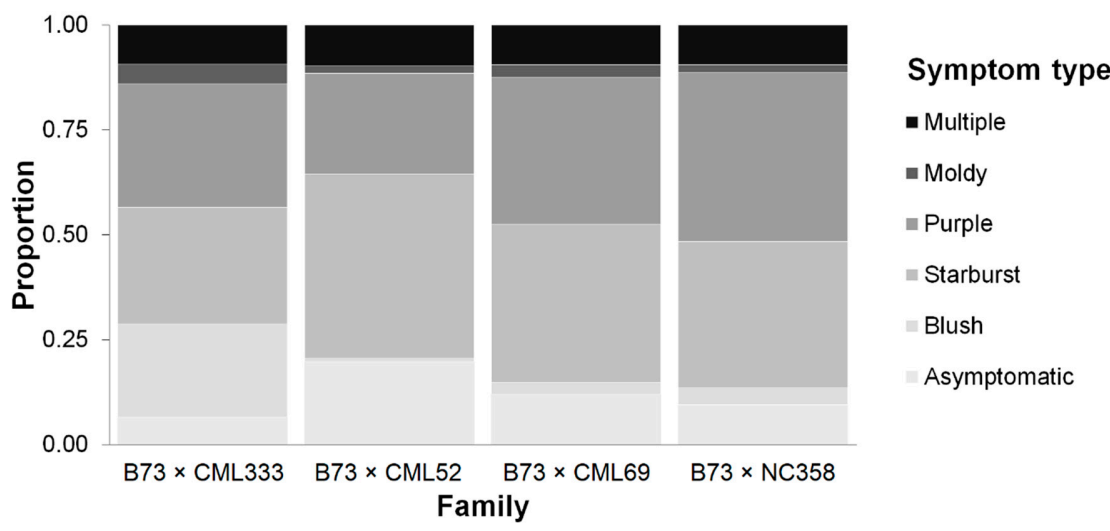

Figure 1. Proportions of plots exhibiting distinct symptom types in four RIL families across three environments. 
$\mathrm{BDEN}_{\text {inoc }}$ differed significantly among symptom types in all analyses (ANOVA, $p<0.0001$ ) (Table 2). Pairwise $t$-tests demonstrated that greater external symptom severity was associated with more greatly reduced $\mathrm{BDEN}_{\text {inoc }}$ in all families (Table 2). Specifically, asymptomatic plots had the

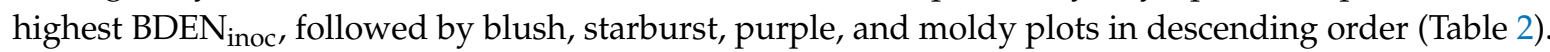

Table 2. Comparison of $B_{\text {DEN }}$ inoc, FER, FUM, and the ratio of FUM to FER (FUM:FER) under F. verticillioides inoculation among plots exhibiting distinct symptom types. Combined and

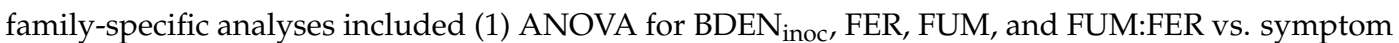
type, and (2) pairwise $t$-tests comparing BDEN $_{\text {inoc }}$,FER, FUM, and FUM:FER between symptom types.

\begin{tabular}{|c|c|c|c|c|c|}
\hline Family & $\begin{array}{c}\text { Symptom } \\
\text { Type }\end{array}$ & $\begin{array}{l}\text { BDEN }_{\text {inoc }} \\
\left(\mathrm{g} \mathrm{mL}^{-1}\right)\end{array}$ & $\begin{array}{c}\text { FER } \\
(\%)\end{array}$ & $\begin{array}{l}\text { FUM } \\
(\mathrm{ppm})\end{array}$ & $\begin{array}{c}\text { FUM:FER } \\
\left(\text { ppm }^{-1}\right)\end{array}$ \\
\hline \multirow[t]{6}{*}{ Combined } & Asym. & $0.693 \pm 0.003 \mathrm{~A}$ & $19.58 \pm 0.44 \mathrm{E}$ & $10.79 \pm 1.69 \mathrm{~A}$ & $0.96 \pm 0.009 \mathrm{~A}$ \\
\hline & Blush & $0.682 \pm 0.005 \mathrm{~A}$ & $56.59 \pm 1.88 \mathrm{C}$ & $15.51 \pm 6.64 \mathrm{C}$ & $0.73 \pm 0.017 \mathrm{C}$ \\
\hline & Starburst & $0.656 \pm 0.003 \mathrm{~B}$ & $65.54 \pm 0.75 \mathrm{~B}$ & $18.40 \pm 1.90 \mathrm{~B}$ & $0.75 \pm 0.008 \mathrm{C}$ \\
\hline & Purple & $0.641 \pm 0.003 \mathrm{C}$ & $50.51 \pm 0.82 \mathrm{D}$ & $38.39 \pm 4.75 \mathrm{BC}$ & $0.78 \pm 0.009 \mathrm{~B}$ \\
\hline & Moldy & $0.576 \pm 0.013 \mathrm{D}$ & $76.14 \pm 2.64 \mathrm{~A}$ & $97.66 \pm 38.54 \mathrm{~A}$ & $0.79 \pm 0.038 \mathrm{BC}$ \\
\hline & ANOVA $p$ & $<0.0001^{* * *}$ & $<0.0001^{* * *}$ & $0.0002^{* *}$ & $<0.0001^{* * *}$ \\
\hline $\mathrm{B} 73 \times$ & Asym. & $0.713 \pm 0.007 \mathrm{~A}$ & $19.73 \pm 1.36 \mathrm{C}$ & $4.58 \pm 0.92 \mathrm{AB}$ & $0.91 \pm 0.02 \mathrm{~A}$ \\
\hline \multirow[t]{5}{*}{ CML333 } & Blush & $0.691 \pm 0.005 \mathrm{~B}$ & $58.68 \pm 2.20 \mathrm{~B}$ & $14.35 \pm 5.01 \mathrm{AB}$ & $0.74 \pm 0.02 \mathrm{~B}$ \\
\hline & Starburst & $0.685 \pm 0.006 \mathrm{~B}$ & $70.49 \pm 1.49 \mathrm{~A}$ & $13.80 \pm 3.12 \mathrm{~A}$ & $0.73 \pm 0.02 \mathrm{~B}$ \\
\hline & Purple & $0.658 \pm 0.006 C$ & $54.04 \pm 1.79 \mathrm{~B}$ & $31.19 \pm 10.31 \mathrm{~B}$ & $0.71 \pm 0.02 \mathrm{~B}$ \\
\hline & Moldy & $0.601 \pm 0.021 \mathrm{D}$ & $77.95 \pm 3.77 \mathrm{~A}$ & $85.22 \pm 53.51 \mathrm{AB}$ & $0.73 \pm 0.07 \mathrm{~B}$ \\
\hline & ANOVA $p$ & $<0.0001^{* * *}$ & $<0.0001^{* * *}$ & $0.0427^{*}$ & $0.0001^{* *}$ \\
\hline B73 $\times$ & Asym. & $0.688 \pm 0.005 \mathrm{~A}$ & $18.09 \pm 0.68 \mathrm{D}$ & $6.17 \pm 0.70 \mathrm{~A}$ & $0.94 \pm 0.01 \mathrm{~A}$ \\
\hline \multirow[t]{5}{*}{ CML52 } & Blush & $0.606 \pm 0.020 \mathrm{~B}$ & $46.78 \pm 7.61 \mathrm{BC}$ & $8.75 \pm 8.17 \mathrm{AB}$ & $0.70 \pm 0.07 \mathrm{BC}$ \\
\hline & Starburst & $0.660 \pm 0.004 \mathrm{~B}$ & $59.81 \pm 1.32$ B & $10.46 \pm 2.16 \mathrm{AB}$ & $0.74 \pm 0.01 \mathrm{C}$ \\
\hline & Purple & $0.655 \pm 0.008 \mathrm{~B}$ & $41.05 \pm 1.57 \mathrm{C}$ & $21.21 \pm 7.81 \mathrm{~B}$ & $0.78 \pm 0.02 \mathrm{~B}$ \\
\hline & Moldy & $0.503 \pm 0.039 \mathrm{C}$ & $84.19 \pm 5.38 \mathrm{~A}$ & $32.09 \pm 24.56 \mathrm{AB}$ & $0.66 \pm 0.08 \mathrm{BC}$ \\
\hline & ANOVA $p$ & $<0.0001^{* * *}$ & $<0.0001^{* * *}$ & 0.113 & $<0.0001^{* * *}$ \\
\hline $\mathrm{B} 73 \times$ & Asym. & $0.693 \pm 0.004 \mathrm{~A}$ & $21.47 \pm 0.79 \mathrm{C}$ & $14.70 \pm 4.11 \mathrm{AB}$ & $0.99 \pm 0.01 \mathrm{~A}$ \\
\hline \multirow[t]{5}{*}{ CML69 } & Blush & $0.659 \pm 0.016 \mathrm{AB}$ & $46.36 \pm 6.61 \mathrm{~B}$ & $39.96 \pm 25.15 \mathrm{BC}$ & $0.78 \pm 0.07 \mathrm{BC}$ \\
\hline & Starburst & $0.657 \pm 0.005 \mathrm{~B}$ & $67.74 \pm 1.40 \mathrm{~A}$ & $21.59 \pm 4.09 \mathrm{C}$ & $0.75 \pm 0.02 \mathrm{C}$ \\
\hline & Purple & $0.644 \pm 0.006 \mathrm{~B}$ & $54.22 \pm 1.63 \mathrm{~B}$ & $42.20 \pm 8.61 \mathrm{C}$ & $0.78 \pm 0.02 \mathrm{BC}$ \\
\hline & Moldy & $0.588 \pm 0.021 \mathrm{C}$ & $72.49 \pm 5.74 \mathrm{~A}$ & $179.86 \pm 116.91 \mathrm{~A}$ & $0.88 \pm 0.07 \mathrm{AB}$ \\
\hline & ANOVA $p$ & $<0.0001^{* * *}$ & $<0.0001^{* * *}$ & $0.015^{*}$ & $<0.0001^{* * *}$ \\
\hline $\mathrm{B} 73 \times$ & Asym. & $0.692 \pm 0.006 \mathrm{~A}$ & $20.88 \pm 0.85 \mathrm{D}$ & $21.91 \pm 7.24 \mathrm{~A}$ & $0.97 \pm 0.02 \mathrm{~A}$ \\
\hline \multirow[t]{5}{*}{ NC358 } & Blush & $0.654 \pm 0.016 \mathrm{AB}$ & $56.06 \pm 4.60 \mathrm{BC}$ & $4.93 \pm 1.84 \mathrm{~B}$ & $0.67 \pm 0.05 \mathrm{D}$ \\
\hline & Starburst & $0.617 \pm 0.006 \mathrm{~B}$ & $66.45 \pm 1.68 \mathrm{~A}$ & $29.82 \pm 5.56 \mathrm{~A}$ & $0.77 \pm 0.02 \mathrm{CD}$ \\
\hline & Purple & $0.623 \pm 0.006 \mathrm{~B}$ & $51.19 \pm 1.40 \mathrm{C}$ & $53.31 \pm 10.22 \mathrm{~A}$ & $0.82 \pm 0.02 \mathrm{~B}$ \\
\hline & Moldy & $0.562 \pm 0.029 \mathrm{C}$ & $68.74 \pm 7.55 \mathrm{AB}$ & $60.22 \pm 31.84 \mathrm{~A}$ & $0.89 \pm 0.08 \mathrm{ABC}$ \\
\hline & ANOVA $p$ & $<0.0001^{* * *}$ & $<0.0001^{* * *}$ & 0.0502 & $<0.0001^{* * *}$ \\
\hline
\end{tabular}

ANOVA and pairwise $t$-tests were conducted on Box-Cox transformed data. Box-Cox-transformed means and standard errors $( \pm)$ are reported. Groups not connected by the same letter within each column/family are significantly different (pairwise two-tailed $t$-tests, $p<0.05$ ). ANOVA significance is denoted as $* 0.05>p \geq 0.01$; ** $0.01>p \geq 0.0001 ;{ }^{* * *} p<0.0001$

FER and FUM:FER differed significantly among symptom types in all analyses, but pairwise differences between symptom types varied by family (Table 2). Similarly, symptom types differed significantly with respect to FUM in the combined-family, B73 $\times$ CML333, and B73 $\times$ CML69 analyses, but symptom severity was not clearly linked to FUM contamination (Table 2). Unexpectedly, asymptomatic plots had the highest or second-highest FUM contamination across all families (Table 2). This phenomenon may be the result of the symptom type scoring method, which was conducted with the kernels still attached to the cob and thus kernels may have had symptoms present below the visible area. 


\subsection{Fusarium Ear Rot Severity, Fumonisin Contamination, and Kernel Bulk Density are Correlated}

We assessed correlations among indicators of FVI severity and FUM contamination at the levels of plot phenotype and genotype means (after controlling for genetic and field effects). Across all families, FUM and FER were (1) positively phenotypically and/or genotype-means correlated with each other and (2) negatively phenotypically and genotype-means correlated with BDEN inoc (Table 3). These correlations are consistent with those previously reported $[33,35,43,44]$. FUM tended to be more strongly correlated with BDEN $_{\text {inoc }}$ than with FER across families (Table 3), suggesting that internal infection severity (as reflected by $\mathrm{BDEN}_{\text {inoc }}$ ) may be a better indicator of FUM contamination that external symptom severity (FER).

Table 3. Phenotypic and genotype-mean correlations among $B_{D E N}$ inoc FER, FUM, and the ratio of FUM to FER (FUM:FER) under F. verticillioides inoculation within four NAM RIL families. Phenotypic correlations $\left(\mathrm{r}_{\mathrm{P}}\right)$ among plot-level phenotypes are in the upper diagonals. Correlations among genotype-means $\left(\mathrm{r}_{\mathrm{G}}\right)$ after controlling for genetic and field effects are in the lower diagonals.

\begin{tabular}{|c|c|c|c|c|}
\hline \multicolumn{5}{|c|}{ B73 $\times$ CML333 Family } \\
\hline $\mathbf{r}_{\mathrm{P}} / \mathbf{r}_{\mathrm{G}}$ & BDEN $_{\text {inoc }}$ & FER & FUM & FUM:FER \\
\hline BDEN $_{\text {inoc }}$ & & $-0.46^{* * *}$ & $-0.25^{* * *}$ & $-0.15^{*}$ \\
\hline FER & $-0.53^{* * *}$ & & $0.17^{* *}$ & $-0.18^{* *}$ \\
\hline FUM & $-0.31^{* *}$ & $0.28^{* * *}$ & & $0.94 * * *$ \\
\hline FUM:FER & 0.02 & $-0.33^{* * *}$ & $0.80^{* * *}$ & \\
\hline \multicolumn{5}{|c|}{ B73 $\times$ CML52 family } \\
\hline $\mathrm{r}_{\mathrm{P}} / \mathrm{r}_{\mathrm{G}}$ & BDEN $_{\text {inoc }}$ & FER & FUM & FUM:FER \\
\hline BDEN $_{\text {inoc }}$ & & $-0.47^{* * *}$ & $-0.12 *$ & 0.12 * \\
\hline FER & $-0.48^{* * *}$ & & $0.08 \mathrm{~ms}$ & $-0.36^{* * *}$ \\
\hline FUM & $-0.18 *$ & $0.20 *$ & & $0.90^{* * *}$ \\
\hline FUM:FER & $0.15^{*}$ & $-0.46^{* * *}$ & $0.75^{* * *}$ & \\
\hline \multicolumn{5}{|c|}{ B73 $\times$ CML69 family } \\
\hline $\mathbf{r}_{\mathrm{P}} / \mathbf{r}_{\mathrm{G}}$ & BDEN $_{\text {inoc }}$ & FER & FUM & FUM:FER \\
\hline BDEN $_{\text {inoc }}$ & & $-0.55^{* * *}$ & $-0.30^{* * *}$ & 0.02 \\
\hline FER & $-0.53^{* * *}$ & & -0.01 & $-0.33^{* * *}$ \\
\hline FUM & $-0.27^{* *}$ & $0.21 * *$ & & $0.95^{* * *}$ \\
\hline FUM:FER & 0.06 & $-0.39^{* * *}$ & $0.81^{* * *}$ & \\
\hline \multicolumn{5}{|c|}{ B73 $\times$ NC358 family } \\
\hline $\mathrm{r}_{\mathrm{P}} / \mathrm{r}_{\mathrm{G}}$ & BDEN $_{\text {inoc }}$ & FER & FUM & FUM:FER \\
\hline BDEN $_{\text {inoc }}$ & & $-0.59 * * *$ & $-0.19 * *$ & $0.11 \mathrm{~ms}$ \\
\hline FER & $-0.58^{* * *}$ & & $0.21^{* * *}$ & $-0.14^{* *}$ \\
\hline FUM & $-0.25^{* *}$ & 0.12 & & $0.94^{* * *}$ \\
\hline FUM:FER & $0.15^{\mathrm{ms}}$ & $-0.46^{* * *}$ & $0.79 * * *$ & \\
\hline
\end{tabular}

Pearson correlation coefficients are reported in each cell, and significance is denoted as ${ }^{\mathrm{ms}} 0.1>p \geq 0.05$ (marginally significant); ${ }^{*} 0.05>p \geq 0.01 ; * * 0.01>p \geq 0.0001 ;{ }^{* * *} p<0.0001$.

\subsection{Innate Ear Morphology is a Component of Resistance to FVI and FUM Contamination}

Previous studies have reported associations between FVI severity and FUM contamination with characteristics of the cob and kernel tissues, such as cob morphology and kernel density-related traits [28,32-34,45-47]. Given the symptomatological variation present in the four RIL families, we sought to test the extent to which innate (uninoculated) ear architecture played a role in resistance to FVI using publicly available data on cob density (CobDen), diameter (CobDiam), length (CobLen), mass (CobMass), and volume (CobVol) as well as uninoculated kernel bulk density $\left(\mathrm{BDEN}_{\text {uninoc }}\right)$.

Supporting the hypothesis that maize lines with greater innate kernel bulk density $\left(\mathrm{BDEN}_{\text {uninoc }}\right)$ in turn have greater bulk density under F. verticillioides inoculation $\left(\mathrm{BDEN}_{\text {inoc }}\right)$, we found that $\mathrm{BDEN}_{\text {uninoc }}$

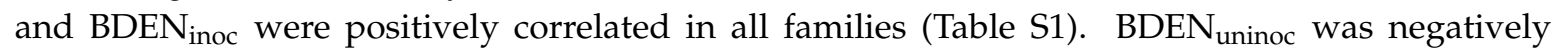


correlated with FER in the B73 $\times$ CML52 and B73 $\times$ CML69 families and positively correlated with

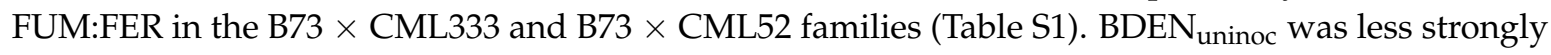
correlated with FER and FUM:FER than was BDEN inoc (Tables 3 and 4). Unlike the correlations found

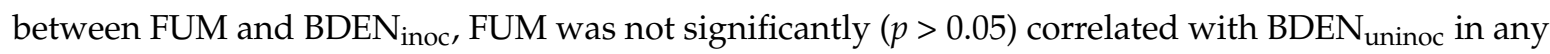
family (Table S1).

Table 4. Genotypic and field effect variance proportions, significance of days to silking (DTS), and

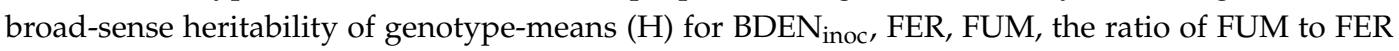
(FUM:FER), and the absence/presence of five symptom types (asymptomatic, blush, starburst, purple, moldy) under F. verticillioides inoculation within four NAM RIL families. Mixed linear models were fit with genotype, environment (env), genotype ${ }^{*}$ environment $\left(\mathrm{G}^{*} \mathrm{E}\right)$, block[environment] $(\mathrm{B}[\mathrm{E}])$ as random effects and DTS as a fixed effect.

\begin{tabular}{|c|c|c|c|c|c|c|c|c|}
\hline \multirow[t]{2}{*}{ Family } & \multirow[t]{2}{*}{ Trait } & \multicolumn{5}{|c|}{$\begin{array}{c}\text { Random Effects } \\
\text { (Variance Proportions) }\end{array}$} & \multirow{2}{*}{$\begin{array}{c}\begin{array}{c}\text { Fixed Effect } \\
(p \text {-Value })\end{array} \\
\text { DTS }\end{array}$} & \multirow[t]{2}{*}{$\mathbf{H}$} \\
\hline & & Genotype & Env. & $G^{*} E$ & $\mathrm{~B}[\mathrm{E}]$ & Error & & \\
\hline \multirow{9}{*}{$\begin{array}{c}\text { B73 } \times \\
\text { CML333 }\end{array}$} & $\mathrm{BDEN}_{\text {inoc }}$ & 0.64 & 0.01 & 0.04 & 0 & 0.31 & 0.1 & 0.79 \\
\hline & FER & 0.42 & 0.01 & 0.12 & 0 & 0.45 & 0.9 & 0.75 \\
\hline & FUM & 0.02 & 0.61 & 0.16 & 0 & 0.21 & 0.3 & 0.12 \\
\hline & FUM:FER & 0.03 & 0.58 & 0.10 & 0 & 0.29 & 0.6 & 0.17 \\
\hline & Asymptomatic & 0.05 & 0.07 & 0.17 & 0.02 & 0.69 & 0.2 & 0.15 \\
\hline & Blush & 0.18 & 0.13 & 0.30 & 0.01 & 0.38 & $0.004^{* *}$ & 0.44 \\
\hline & Starburst & 0.12 & 0.18 & 0.17 & 0.01 & 0.53 & 0.9 & 0.33 \\
\hline & Purple & 0.04 & 0.25 & 0.12 & 0.03 & 0.56 & 0.5 & 0.16 \\
\hline & Moldy & 0.17 & 0.03 & 0.80 & 0 & 0.001 & 0.3 & 0.40 \\
\hline \multirow{9}{*}{$\begin{array}{l}\text { B73 × } \\
\text { CML52 }\end{array}$} & $\mathrm{BDEN}_{\text {inoc }}$ & 0.33 & 0.003 & 0 & 0.04 & 0.62 & $0.002 * *$ & 0.52 \\
\hline & FER & 0.30 & 0.20 & 0.06 & 0.03 & 0.41 & $0.03^{*}$ & 0.72 \\
\hline & FUM & 0.03 & 0.46 & 0.01 & 0.04 & 0.46 & 0.1 & 0.17 \\
\hline & FUM:FER & 0.02 & 0.48 & 0 & 0.01 & 0.48 & 0.3 & 0.12 \\
\hline & Asymptomatic & 0.06 & 0.27 & 0.17 & 0.03 & 0.48 & 0.8 & 0.21 \\
\hline & Blush & 0 & 0.01 & 0 & 0 & 0.99 & 0.04 * & 0 \\
\hline & Starburst & 0.11 & 0.28 & 0.18 & 0.02 & 0.42 & 0.6 & 0.35 \\
\hline & Purple & 0.03 & 0.30 & 0.20 & 0.01 & 0.46 & 0.4 & 0.13 \\
\hline & Moldy & 0.31 & 0.01 & 0.68 & 0 & $1 \times 10^{-5}$ & 0.8 & 0.58 \\
\hline \multirow{9}{*}{$\begin{array}{l}\text { B73 } \times \\
\text { CML69 }\end{array}$} & $\mathrm{BDEN}_{\text {inoc }}$ & 0.46 & 0.03 & 0.32 & 0.02 & 0.18 & $0.04 *$ & 0.65 \\
\hline & FER & 0.22 & 0.14 & 0.18 & 0.03 & 0.43 & 0.8 & 0.59 \\
\hline & FUM & 0.02 & 0.70 & 0.13 & 0.01 & 0.14 & 0.1 & 0.15 \\
\hline & FUM:FER & 0.02 & 0.70 & 0.07 & 0.02 & 0.19 & 0.3 & 0.21 \\
\hline & Asymptomatic & 0.09 & 0.13 & 0.16 & 0 & 0.62 & 0.2 & 0.25 \\
\hline & Blush & 0.06 & 0.04 & 0.01 & 0 & 0.88 & 0.05 & 0.18 \\
\hline & Starburst & 0.08 & 0.24 & 0.15 & 0.003 & 0.53 & $0.005^{* *}$ & 0.27 \\
\hline & Purple & 0.07 & 0.26 & 0.21 & 0.01 & 0.46 & $0.03 *$ & 0.24 \\
\hline & Moldy & 0.17 & 0.03 & 0.80 & 0 & $8 \times 10^{-5}$ & $0.009 * *$ & 0.39 \\
\hline \multirow{9}{*}{$\begin{array}{c}\mathrm{B} 73 \times \\
\mathrm{NC} 358\end{array}$} & $\mathrm{BDEN}_{\text {inoc }}$ & 0.23 & 0.08 & 0.56 & 0.02 & 0.12 & 0.07 & 0.40 \\
\hline & FER & 0.27 & 0.22 & 0.06 & 0.04 & 0.40 & $0.003 * *$ & 0.70 \\
\hline & FUM & 0.01 & 0.73 & 0.04 & 0 & 0.22 & 0.7 & 0.14 \\
\hline & FUM:FER & 0.03 & 0.65 & 0.06 & 0 & 0.27 & 0.7 & 0.19 \\
\hline & Asymptomatic & 0.05 & 0.04 & 0 & 0.05 & 0.86 & 0.08 & 0.15 \\
\hline & Blush & 0.11 & 0.02 & 0.87 & 0 & 0.001 & 0.9 & 0.28 \\
\hline & Starburst & 0.06 & 0.20 & 0.03 & 0.01 & 0.70 & $0.003 * *$ & 0.21 \\
\hline & Purple & 0.07 & 0.25 & 0 & 0.01 & 0.67 & $0.03 *$ & 0.24 \\
\hline & Moldy & 0.13 & 0.01 & 0.85 & 0 & 0.002 & 0.4 & 0.32 \\
\hline
\end{tabular}

Fixed effect $p$-value significance is denoted as: ${ }^{*} 0.05>p \geq 0.01 ;{ }^{* *} 0.01>p \geq 0.0001$.

Although the statistical significance of correlations between cob size traits and $\mathrm{BDEN}_{\text {inoc }}$ or $\mathrm{BDEN}_{\text {uninoc }}$ varied among families, the directionality of these correlations was generally conserved across families (Table S1). Both $\mathrm{BDEN}_{\text {inoc }}$ and $\mathrm{BDEN}_{\text {uninoc }}$ tended to be negatively correlated with 
CobDiam, CobMass, and CobVol (Table S1). Relationships between cob morphology and FER, FUM, and FUM:FER varied from family to family. In general, lines with larger cobs had greater FER severity, as demonstrated by positive correlations between FER and CobDiam or CobVol across families (Table S1). FER was negatively correlated with CobDen in the B73 $\times$ CML52 family and positively correlated with CobMass in the B73 $\times$ NC358 family (Table S1). FUM:FER correlations with cob size and/or density in the B73 $\times$ CML52 and B73 $\times$ NC358 families revealed that lines with larger, less dense cobs had reduced FUM:FER (Table S1). We expected to find similar relationships between FUM and cob morphology, but instead found that FUM was only marginally positively correlated with CobMass in the B73 $\times$ CML52 family. This may have been due to the low genetic variation for FUM in this study. Similar to previous studies [33,36], cob size traits (CobDiam, CobLen, CobVol) were significantly $(p<0.05)$ or marginally significantly $(p<0.1)$ positively correlated with each other and with CobMass. CobDen was significantly positively correlated with CobMass and significantly or marginally significantly negatively correlated with cob size traits (Table S1).

\subsection{Genetic and Environmental Variation on Disease Severity Differ among Families}

We assessed genetic and environmental effects on indicators of FVI severity within and among families. Across all families, broad-sense heritability of genotype-means $(\mathrm{H})$ was greater for $\mathrm{BDEN}_{\text {inoc }}$ $(0.4-0.79)$ and FER (0.59-0.75) than for FUM (0.12-0.17), FUM:FER (0.12-0.21), or symptom type traits (0-0.44) (Table 4, Figure 2). The variance explained by genotype, environment and the interaction between genotype and environment $\left(G^{*} \mathrm{E}\right)$ varied widely by trait and family (Table 4$)$. Of the nine FVI traits, the moldy symptom type was most affected by $\mathrm{G}^{*} \mathrm{E}(68 \%$ to $85 \%$ variance in all families) (Table 4$)$. In general, $\mathrm{G}^{*} \mathrm{E}$ explained less than $20 \%$ of the variance in all other traits across families (Table 4). Traits related to fumonisin contamination (FUM and FUM:FER) had lower genetic variance (1\% to 3\%) and higher variance explained by environment (46\% to $73 \%$ ) than the other traits across all families (Table 4). In contrast, $\mathrm{BDEN}_{\text {inoc }}$ and FER had the highest genetic variance $\left(\mathrm{BDEN}_{\text {inoc }}=23 \%\right.$ to $64 \%$; $\mathrm{FER}=22 \%$ to $42 \%)$, and environment explained the least amount of variance in $\mathrm{BDEN}_{\text {inoc }}(0.3 \%$ to $8 \%)$ and the moldy symptom type (1\% to 3\%) (Table 4 ). The H for FUM found in our experiment was much lower than those previously reported $(0.43-0.86)[43,44]$. Resistance to mycotoxigenic fungi and kernel composition are influenced by environmental conditions and management practices $[13,19,36,37,48-51]$, which may explain the large environmental and $G^{*} E$ effects here.

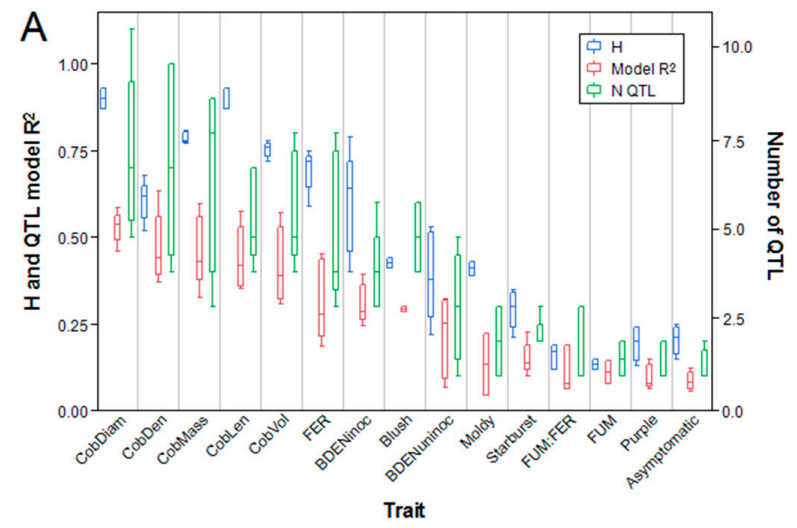

B

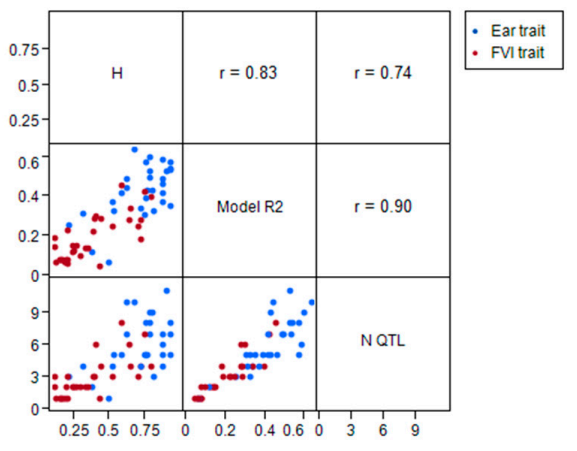

Figure 2. (A) Box-plots comparing $H$, number of associated quantitative trait loci (QTL), and variance

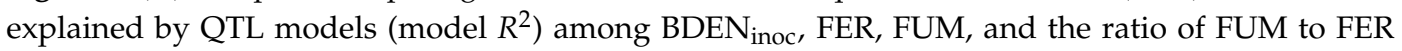
(FUM:FER) under F. verticillioides inoculation, and kernel bulk density (BDEN uninoc $_{\text {) }}$ and cob density, diameter, length, mass, and volume under uninoculated conditions. (B) Pearson correlations among $\mathrm{H}$, number of associated QTL, and QTL model $R^{2}$ for the previously described F. verticillioides infection (FVI) and ear traits ( $p<0.0001$ for all three pairwise correlations). 


\subsection{Genetic Architecture Differs between Ear Morphological and Resistance Traits}

In total, stepwise regression selected 271 quantitative trait loci (QTL) associated with the nine FVI traits and the six ear traits in the single and joint family models from the total set of 7386 markers (Table S2). Sixty-six QTL were selected in the joint family models, and 57, 41, 59, and 48 QTL were mapped in the B73 $\times$ CML333, B73 $\times$ CML52, B73 $\times$ CML69, and B73 $\times$ NC358 families, respectively (Table S2). Traits that had greater $\mathrm{H}$ also had a greater number of associated QTL and greater variance explained by their respective QTL models (model $R^{2}$ ) (Figure 2). Cob morphological traits tended to have a greater number of associated QTL (28-37 QTL each) and QTL model $R^{2}$ (model $R^{2}=0.31-0.63$ )

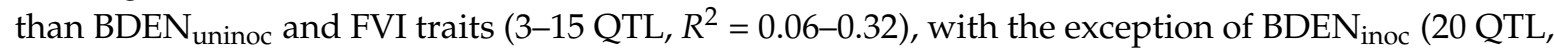
model $R^{2}=0.28-0.39$ ), FER ( 26 QTL, $\left.R^{2}=0.18-0.45\right)$, and the blush symptom type (10 QTL, model $R^{2}=0.29-0.30$ ) (Figure 2).

\subsection{Most QTL for Resistance to F. verticillioides are Trait-Specific}

Within families, the majority of QTL were specific to one trait (161/271 QTL) (Table S3). A total of 110 QTL overlapped with QTL for at least one other trait within families at 44 distinct regions ("colocalized QTL") (Table S3). Twenty-one colocalized QTL were associated with multiple ear traits but not associated with any FVI trait (Table S3). Ten colocalized QTL were associated with multiple FVI traits but no ear traits ("FVI-specific colocalized QTL"), with three each from the B73 $\times$ CML69 and B73 $\times$ CML333 families, two from the B73 $\times$ NC358 family, and one each from the B73 $\times$ CML52 and joint family analyses (Table 5). Thirteen colocalized QTL were associated with both FVI and ear traits ("FVI-ear colocalized QTL"), with five from the joint analysis, three from the B73 $\times$ CML52 family, three from the B73 $\times$ CML333 family, and one each from the B73 $\times$ CML69 and B73 $\times$ NC358 families (Table 5).

Table 5. Physical positions (AGPv2) and marker effects of colocalized QTL. Marker effects were nested within family in the joint family stepwise regression model. As such, each colocalized QTL from the joint family analysis has four marker effects from the four non-B73 alleles (CML333, CML52, CML69, NC358) vs. the B73 allele. Colocalized QTL from the single-family analyses have one marker effect each (non-B73 parent allele vs. B73 allele).

\begin{tabular}{|c|c|c|c|c|}
\hline Analysis & Chr. & $\begin{array}{l}\text { Position } \\
\quad(b p)\end{array}$ & $\begin{array}{l}\text { Associated } \\
\text { Traits }\end{array}$ & $\begin{array}{l}\text { Marker Effect on Trait } \\
\text { (Non-B73 vs. B73 Allele) }\end{array}$ \\
\hline \multirow[t]{6}{*}{$\begin{array}{l}\text { Joint } \\
\text { family }\end{array}$} & 1 & $\begin{array}{l}17,256,105- \\
25,068,060\end{array}$ & $\begin{array}{l}\text { BDEN }_{\text {inoc }} \\
\text { Blush } \\
\text { CobLen }\end{array}$ & $\begin{array}{l}+0.003_{\text {CML333 }} ;+0.013_{\text {CML52 }} ;+0.019_{\text {CML69 }} ;-0.001_{\text {NC358 }} \\
+0.054_{\text {CML333 }} ;+0.002_{\text {CML52 }} ;-0.001_{\text {CML69 }} ;+0.007_{\text {NC358 }} \\
-4.874_{\text {CML333 }} ;-3.899_{\text {CML52 }} ;-5.097_{\text {CML } 69} ;-13.611_{\text {NC358 }}\end{array}$ \\
\hline & 2 & $\begin{array}{l}20,081,914- \\
50,634,516\end{array}$ & $\begin{array}{l}\text { Blush } \\
\text { CobDiam } \\
\text { CobLen } \\
\text { CobMass } \\
\text { CobVol } \\
\text { Moldy } \\
\text { Starburst }\end{array}$ & 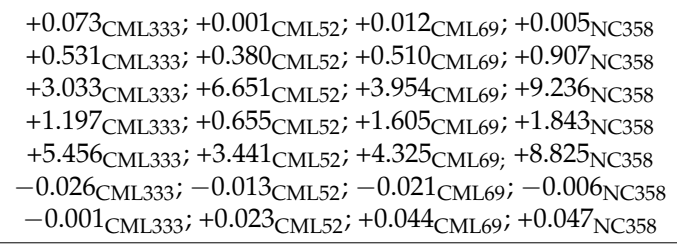 \\
\hline & 2 & $\begin{array}{c}193,400,572- \\
196,813,641\end{array}$ & $\begin{array}{l}\text { BDEN }_{\text {inoc }} \\
\text { CobMass }\end{array}$ & $\begin{array}{l}+0.025_{\text {CML333 }} ;+0.003_{\text {CML52 }} ;+0.010_{\text {CML69 }} ;+0.002_{\mathrm{NC} 358} \\
-1.545_{\text {CML333 }} ;+0.418_{\text {CML52 }} ;-1.314_{\text {CML69 }} ;+0.220_{\text {NC358 }}\end{array}$ \\
\hline & 5 & $\begin{array}{c}205,258,663- \\
208,297,027\end{array}$ & $\begin{array}{l}\text { BDEN }_{\text {inoc }} \\
\text { Blush } \\
\text { CobLen } \\
\text { FER }\end{array}$ & 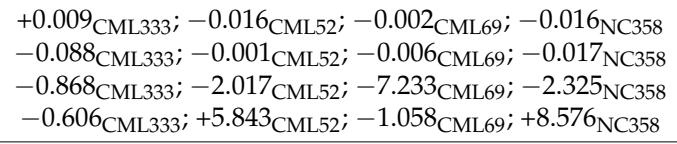 \\
\hline & 6 & $\begin{array}{c}130,721,405- \\
133,795,910\end{array}$ & $\begin{array}{l}\text { Asym } \\
\text { FER }\end{array}$ & $\begin{array}{l}+0.002_{\text {CML333 }} ;+0.027_{\text {CML } 52} ;+0.015_{\text {CML } 69} ;+0.007_{\text {NC358 }} \\
-4.192_{\text {CML333 }} ;-6.906_{\text {CML52 }} ;-6.253_{\text {CML } 69} ;-4.148_{\text {NC358 }}\end{array}$ \\
\hline & 10 & $\begin{array}{l}79,389,587- \\
116,043,385\end{array}$ & $\begin{array}{l}\text { CobDen } \\
\text { Starburst }\end{array}$ & $\begin{array}{l}+0.005_{\text {CML333 }} ;+0.012_{\text {CML52 }} ;+0.0003_{\text {CML69 }} ;+0.007_{\text {NC358 }} \\
-0.031_{\text {CML333 }} ;-0.037_{\text {CML52 }} ;-0.029_{\text {CML } 69} ;-0.048_{\text {NC358 }}\end{array}$ \\
\hline
\end{tabular}


Table 5. Cont.

\begin{tabular}{|c|c|c|c|c|}
\hline Analysis & Chr. & $\begin{array}{l}\text { Position } \\
\quad \text { (bp) }\end{array}$ & $\begin{array}{l}\text { Associated } \\
\text { Traits }\end{array}$ & $\begin{array}{l}\text { Marker Effect on Trait } \\
\text { (Non-B73 vs. B73 Allele) }\end{array}$ \\
\hline \multirow[t]{6}{*}{$\begin{array}{c}\text { B73 } \times \\
\text { CML333 }\end{array}$} & 1 & $\begin{array}{c}19,128,807- \\
24,311,471\end{array}$ & $\begin{array}{l}\text { Blush } \\
\text { CobLen }\end{array}$ & $\begin{array}{l}+0.052_{\text {CML } 333} \\
-5.937_{\text {CML333 }}\end{array}$ \\
\hline & 1 & $\begin{array}{c}47,813,030- \\
57,347,172\end{array}$ & $\begin{array}{l}\text { FER } \\
\text { FUM }\end{array}$ & $\begin{array}{l}+6.660_{\text {CML333 }} \\
+0.162_{\text {CML333 }}\end{array}$ \\
\hline & 2 & $\begin{array}{c}21,767,606- \\
35,311,519 \\
\end{array}$ & $\begin{array}{l}\text { BDEN }_{\text {inoc }} \\
\text { Blush }\end{array}$ & $\begin{array}{l}+0.020_{\text {CML } 333} \\
+0.065_{\text {CML333 }}\end{array}$ \\
\hline & 7 & $\begin{array}{l}4,823,956- \\
6,178,479\end{array}$ & $\begin{array}{l}\text { CobLen } \\
\text { CobVol } \\
\text { Starburst }\end{array}$ & $\begin{array}{c}+6.465_{\mathrm{CML} 333} \\
+15.265_{\mathrm{CML} 333} \\
+0.046_{\mathrm{CML} 333}\end{array}$ \\
\hline & 7 & $\begin{array}{l}14,152,199- \\
23,748,237\end{array}$ & $\begin{array}{c}\text { FER } \\
\text { FUM:FER }\end{array}$ & $\begin{array}{l}+4.985_{\text {CML333 }} \\
-0.009_{\text {CML333 }}\end{array}$ \\
\hline & 8 & $\begin{array}{c}130,983,626- \\
151,773,181\end{array}$ & $\begin{array}{l}\text { BDEN }_{\text {inoc }} \\
\text { CobDen } \\
\text { CobDiam } \\
\text { Starburst }\end{array}$ & $\begin{array}{l}+0.015_{\text {CML333 }} \\
+0.010_{\text {CML333 }} \\
-1.587_{\text {CML333 }} \\
+0.040_{\text {CML333 }}\end{array}$ \\
\hline \multirow[t]{4}{*}{$\begin{array}{l}\text { B73 } \times \\
\text { CML52 }\end{array}$} & 5 & $\begin{array}{l}83,007,601- \\
140,575,190 \\
\end{array}$ & $\begin{array}{l}\text { BDEN }_{\text {inoc }} \\
\text { BDEN }_{\text {uninoc }}\end{array}$ & $\begin{array}{l}+0.018_{\text {CML52 }} \\
+0.009_{\text {CML52 }}\end{array}$ \\
\hline & 6 & $\begin{array}{c}129,994,297- \\
140,630,780 \\
\end{array}$ & $\begin{array}{l}\text { Asym } \\
\text { CobDiam }\end{array}$ & $\begin{array}{l}+0.027_{\text {CML52 }} \\
-0.744_{\text {CML } 52}\end{array}$ \\
\hline & 6 & $\begin{array}{c}154,530,689- \\
156,104,230\end{array}$ & $\begin{array}{c}\text { FER } \\
\text { FUM:FER }\end{array}$ & $\begin{array}{l}-7.612_{\text {CML52 }} \\
+0.010_{\text {CML52 }}\end{array}$ \\
\hline & 8 & $\begin{array}{c}132,405,651- \\
146,365,593\end{array}$ & $\begin{array}{l}\text { BDEN }_{\text {uninoc }} \\
\text { CobVol } \\
\text { FER }\end{array}$ & $\begin{array}{l}+0.010_{\text {CML52 }} \\
-6.924_{\text {CML52 }} \\
-5.718_{\text {CML52 }}\end{array}$ \\
\hline \multirow[t]{4}{*}{$\begin{array}{c}\text { B73 } \times \\
\text { CML69 }\end{array}$} & 2 & $\begin{array}{l}49,846,838- \\
87,089,680\end{array}$ & $\begin{array}{l}\text { CobMass } \\
\text { Moldy } \\
\text { Starburst }\end{array}$ & $\begin{array}{l}+2.016_{\text {CML69 }} \\
-0.023_{\text {CML69 }} \\
+0.048_{\text {CML69 }}\end{array}$ \\
\hline & 4 & $\begin{array}{c}17,330,826- \\
21,710,411\end{array}$ & $\begin{array}{l}\text { BDEN }_{\text {inoc }} \\
\text { FER }\end{array}$ & $\begin{array}{l}-0.018_{\text {CML69 }} \\
+6.347_{\text {CML69 }} \\
\end{array}$ \\
\hline & 4 & $\begin{array}{c}167,066,431- \\
170,804,182\end{array}$ & $\begin{array}{l}\text { Purple } \\
\text { Starburst }\end{array}$ & $\begin{array}{l}+0.034_{\text {CML69 }} \\
-0.050_{\text {CML69 }}\end{array}$ \\
\hline & 7 & $\begin{array}{c}138,072,861- \\
142,429,440\end{array}$ & $\begin{array}{l}\text { Asym } \\
\text { FER }\end{array}$ & $\begin{array}{l}+0.020_{\text {CML69 }} \\
-7.435_{\text {CML69 }}\end{array}$ \\
\hline \multirow[t]{3}{*}{$\begin{array}{c}\text { B73 } \times \\
\text { NC358 }\end{array}$} & 2 & $\begin{array}{c}144,159,847- \\
160,579,525\end{array}$ & $\begin{array}{l}\text { Purple } \\
\text { Starburst }\end{array}$ & $\begin{array}{l}-0.031_{\text {NC358 }} \\
+0.046_{\text {NC358 }}\end{array}$ \\
\hline & 3 & $\begin{array}{l}6,427,177- \\
8,563,589\end{array}$ & $\begin{array}{l}\text { BDEN }_{\text {inoc }} \\
\text { Starburst }\end{array}$ & $\begin{array}{l}+0.021_{\text {NC358 }} \\
-0.054_{\text {NC358 }}\end{array}$ \\
\hline & 10 & $\begin{array}{c}16,505,881- \\
77,678,052\end{array}$ & $\begin{array}{l}\text { Asym } \\
\text { CobDen }\end{array}$ & $\begin{array}{l}+0.018_{\text {NC358 }} \\
+0.009_{\text {NC358 }}\end{array}$ \\
\hline
\end{tabular}

\subsection{Allele Effects at FVI-Specific Loci Reflect Trait Relationships}

The directionality of allele effects on quantitative FVI traits (e.g., FER, FUM) that shared QTL with each other and/or with $\mathrm{BDEN}_{\text {uninoc }}$ generally matched the phenotypic correlation between the corresponding traits. For example, FER was negatively correlated with both $\mathrm{BDEN}_{\text {inoc }}$ and $\mathrm{BDEN}_{\text {uninoc }}$ in the B73 $\times$ CML52 and B73 $\times$ CML69 families (Tables 3 and 5), and allele effects on FER were opposite to allele effects on $\mathrm{BDEN}_{\text {inoc }}$ and $\mathrm{BDEN}_{\text {uninoc }}$ at three colocalized QTL in the B73 $\times$ CML52, B73 $\times$ CML69, and joint family analyses (Table 5). Similarly, FER was positively correlated with FUM and negatively correlated with FUM:FER across all families (Tables 3 and 5), and the allele effect on FER was in the same direction as the allele effect on FUM at a colocalized QTL in the B73 × CML333 family and in the opposite direction as the allele effect on FUM:FER at colocalized QTL in the B73 $\times$ CML333 and B73 $\times$ CML52 families (Table 5).

QTL colocalized for multiple symptom type traits generally had opposite allele effects on mild (e.g., blush, starburst) vs. severe (e.g., purple, moldy) symptom types (Table 5), indicating that 
related mechanisms may underlie the manifestation of similar symptomatologies (blush/starburst or purple/moldy). For example, allele effects on starburst were in the same direction as those on blush and opposite to allele effects on moldy and purple at colocalized QTL (Table 5). Similarly, asymptomatic lines by definition have low FER, and allele effects on FER were opposite to asymptomatic allele effects at their two colocalized QTL (Table 5).

\subsection{Characteristics of Loci Underlying Specific and Ear-Mediated Resistance to F. verticillioides}

We sought to characterize and compare FVI-specific and FVI-ear QTL. First, we tested whether the two classes of resistance loci differed with respect to marker effect size, controlling for trait, family, and QTL length effects. We found that trait and family were significantly $(p<0.0001)$ and marginally significantly $(p<0.1)$ associated with absolute marker effect size, respectively. As the trait scale for FER and CobVol was larger than the other FVI and ear traits, these two traits in turn had larger absolute marker effects. Compared to the other families, the B73 $\times$ NC358 family had greater marker effect sizes and the joint family models had smaller marker effect sizes. We then investigated whether FVI-specific and FVI-ear loci tended to be found in pericentromeric regions, which have lower recombination rates than non-centromeric regions of the genome [52]. The FVI-specific (10/62 QTL) and FVI-ear (4/13 QTL) groups did not significantly differ with respect to the proportion of QTL located in pericentromeric bins $\left(\chi^{2}=1.5, p=0.2\right)$. Several other studies have mapped loci for resistance to F. verticillioides, and we identified which of our FVI-specific and FVI-ear QTL colocalized with previously described FVI loci $[19,49,53-59]$. A significantly greater proportion of our FVI-specific QTL (46/62 QTL) overlapped published FVI loci than did our FVI-ear QTL $(6 / 13)\left(\chi^{2}=4.0, p=0.04\right)$.

\section{Discussion}

Here we dissect the diversity of genetic resistance to FVI and FUM accumulation in four maize RIL families. We further establish the importance of BDEN $\mathrm{Bnoc}_{\text {an }}$ a useful proxy for FUM [33,34], especially given the poor heritability of FUM contamination in maize grain. In addition, we demonstrate that some loci underlying resistance FVI and FUM severity may have trade-offs for agronomically important kernel and cob traits.

At the phenotypic, genetic, and locus levels, $\mathrm{BDEN}_{\text {inoc }}$ was negatively associated with external symptom severity and FUM contamination. These results strengthen the arguments that $\mathrm{BDEN}_{\text {inoc }}$ could be used as a predictor of FUM contamination [28,32-34] and that selection for increased BDEN inoc could indirectly increase resistance to FUM [35], even under conditions resulting in low heritability for FUM. The relatively low heritability for FUM in our experiment may have been due to the inoculation method (insertion of spore-coated toothpick into the developing ear), which has been shown to be less effective for screening genetic sources of resistance to FUM contamination [33,60]. However, toothpick inoculation, which has been shown to be effective at screening ear-mediated resistance mechanisms [33], allowed us to study the role of the cob in resistance to FVI and FUM. We identified 23 novel QTL associated with resistance to FVI, seven of which may be mediated by kernel and cob architecture.

Although no FUM or FUM:FER QTL colocalized with ear QTL in this study, we did find that lines with larger, less dense cobs had greater FER and lower BDEN inoc $_{\text {at }}$ the QTL and trait correlation levels.

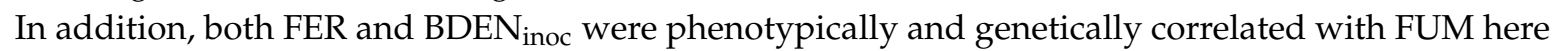
and in previous studies [33,34] and we found substantial overlap between our ear QTL and previously described loci for resistance to FUM [19,49,53-59], suggesting that there may indeed be a genetic link between cob morphology and FUM but that the low heritability for FUM in our experiment may have limited our ability to detect this inferred relationship.

As cob morphology and kernel density are important components of grain yield [36] and quality [61], respectively, increased susceptibility to FVI and FUM contamination may be a by-product of the breeding process. We are currently conducting follow-up experiments with near isogenic lines (NILs) to dissect possible pleiotropy between ear architecture and resistance to FVI and FUM. 
We also recommend that kernel bulk density under F. verticillioides infection be more thoroughly evaluated as a proxy for FUM contamination in maize grain. The wide variation in internal vs. external symptomatology, inter-trait correlations, and QTL colocalizations in this study implies that distinct modes of resistance exist within tropical germplasm, which can be leveraged for resistance breeding.

\section{Materials and Methods}

\subsection{Field Design and Inoculation}

Four RIL families $(B 73 \times$ CML333, B73 $\times$ CML52, B73 $\times$ CML69, B73 $\times$ NC358) from the maize NAM population [40] and the five inbred parents (B73, CML333, CML52, CML69, NC358) were grown at the Central Crops Research Station in Clayton, NC in four year-environments from 2012 to 2015. Each NAM family is composed of 200 RILs. The four non-B73 parents originate from breeding programs in Mexico and North Carolina_regions that are prone to mycotoxin contamination [5,62]—and have previously demonstrated greater resistance to FER than B73 [20,21]. We used an augmented incomplete block design, in which each family was grown separately with 20-plot blocks. RIL plots were replicated once per year-environment and randomized within family, and the two parental lines of each family were randomized in each 20-plot block. All RILs from the B73 $\times$ CML52 and B73 $\times$ NC358 families were grown in four year-environments from 2012 to 2015 . For the B73 $\times$ CML333 and B73 $\times$ CML69 families, all RILs from these two families were grown in three year-environments from 2013 to 2015 and 40 randomly selected RILs from each of these two families were grown in 2012. We measured days to silking (DTS) in each plot as described by Buckler et al. [63]. One toothpick coated with spores from local toxigenic F. verticillioides isolates was inserted into the middle of each developing primary ear approximately 10 days after silking, and the toothpick remained in the ear until harvest [21].

\subsection{Disease Phenotyping}

Primary ears were harvested from each plot at maturity, dried, and then visually evaluated for FER. FER was scored based on the percentage of the kernels presenting symptoms on a $1 \%$ to $100 \%$ scale with 5\% increments [19]. The average FER score of all the ears in each plot was then calculated.

We used a symptom typology to account for the qualitative variation in external FER symptoms, in which each ear was assigned a symptom type: "asymptomatic," "blush," "starburst," "purple," or "moldy" (photographic examples in Morales et al. [33]). Asymptomatic ears had no or very limited visible external symptoms $[33,38,39]$. The blush type was characterized by pink discoloration localized on the kernel crowns [33]. Starburst ears had whitish streaks radiating from the kernel silk scar and/or pedicel $[33,38,64,65]$. The kernels of purple type ears were visibly degraded and had severe purplish discoloration [33]. Moldy ears had severely degraded kernels with matted fungal growth $[33,37,38]$. Each plot was assigned a main symptom type based on the most frequent symptom type of the ears in the plot. Plots with less than 10\% average FER were considered asymptomatic. Plots with equal representation of more than one symptom type were categorized as "multiple."

After scoring FER and symptom typology, ears were then shelled and bulked per plot. From each plot, a random 250-mL volume of kernels was weighed, and kernel bulk density (BDEN inoc $_{\text {) was }}$ calculated as the weight of the kernels divided by $250 \mathrm{~mL}$. After weighing, the kernels were returned to the bulked plot.

All of the kernels in each bulked plot were ground into a fine powder with a Waring 7010 two-speed laboratory blender (Waring Commercial, Inc., Torrington, CT, USA). A 10-g subsample from each ground bulk was put in a $25 \mathrm{~mL}$ centrifuge tube. To extract fumonisins, $20 \mathrm{~mL}$ of $90 \%$ methanol was added to each $25 \mathrm{~mL}$ tube, resulting in a two-fold dilution factor at this step. The tubes were then shaken with a Lab-Line Environ Orbitol Shaker (Lab-Line Instruments, Inc., Melrose Park, IL, USA) at $150 \mathrm{rpm}$ for approximately five minutes. The samples settled for 15 min, after which $0.5 \mathrm{~mL}$ of supernatant from each sample was transferred to a $15 \mathrm{~mL}$ centrifuge tube. To dilute the supernatant to a final 40 -fold dilution, $9.5 \mathrm{~mL}$ of distilled water was added to each $15 \mathrm{~mL}$ tube. 
Fumonisin contamination (FUM) was quantified with FUM-specific enzyme-linked immunosorbent assay (ELISA) kits (Helica Biosystems, Inc., Santa Ana, CA, USA). Absorbance at $450 \mathrm{~nm}$ of the ELISA plates was read using a BioTek $\mu$ Quant ${ }^{\mathrm{TM}}$ microplate spectrophotometer (BioTek Instruments, Inc., Winooski, VT, USA) paired with Gen5 $5^{\mathrm{TM}}$ software (BioTek Instruments, Inc., Winooski, VT, USA). Samples that had FUM levels predicted to be above the highest standard provided by the ELISA kits, $6 \mathrm{\mu g} \mathrm{g}^{-1}$ (ppm), were serially diluted until their predicted FUM levels were within the standard curve. To approximate samples that had non-detectable FUM levels $(<0.1 \mathrm{ppm})$, uniform random values between 0 and $0.1 \mathrm{ppm}$ were assigned to these samples [66]. The ratio of FUM to FER (FUM:FER) was calculated as FUM/(FER+1).

\subsection{Mixed Models and Heritability Estimation}

For mixed model analysis, we treated each of the five symptom types as absence/presence traits. Each plot was assigned as having the absence (0) or presence (1) of each symptom type. For example, if a plot exhibited the blush symptom type, it was assigned 1 for blush and 0 for asymptomatic, starburst, purple, and moldy. As the raw BDEN $_{\text {inoc }}$, FER, FUM, and FUM:FER data were not normally distributed, they were Box-Cox transformed using JMP ${ }^{\circledR}$ software (SAS Institute Inc., Cary, NC, USA, 1989-2007) for further analysis.

We used JMP ${ }^{\circledR}$ software (SAS Institute Inc., Cary, NC, USA, 1989-2007) to fit mixed linear models for the five symptom type absence/presence traits and the four quantitative traits (Box-Cox-transformed BDEN inoc $_{1}$ FER, FUM, and FUM:FER). Within and among families, mixed models were fit for each of the nine FVI traits as a separate response variable with environment, block[environment], genotype, and genotype*environment as random effects and DTS as a fixed covariate. Variance components from each model were extracted and used to calculate broad-sense heritability $(\mathrm{H})$ as

$$
\frac{\sigma_{G}^{2}}{\sigma_{G}^{2}+\frac{\sigma_{G E}^{2}}{e_{h}}+\frac{\sigma_{\varepsilon}^{2}}{p_{h}}},
$$

where $\sigma_{G}^{2}, \sigma_{G E}^{2}$, and $\sigma_{\varepsilon}^{2}$ are the genotype, genotype environment, and error variances, respectively, and $e_{h}$ and $p_{h}$ are defined as

$$
\begin{aligned}
& e_{h}=\frac{n}{\sum_{i=1}^{n} \frac{1}{e_{i}}}, \\
& p_{h}=\frac{n}{\sum_{i=1}^{n} \frac{1}{p_{i}}},
\end{aligned}
$$

where $n$ is the number of genotypes and $e_{i}$ and $p_{i}$ are the number of environments and plots for the $i^{\text {th }}$ genotype, respectively [67].

We also sought to assess associations between FVI and kernel bulk density $\left(\mathrm{BDEN}_{\text {uninoc }}\right)$ and cob morphology under non-inoculated conditions. Total kernel volume, cob diameter (CobDiam), cob length (CobLen), cob mass (CobMass), and ear mass had been previously measured in the NAM in five location-environments in 2006 (Aurora, NY, USA; Clayton, NC, USA; Homestead, FL, USA; Ponce, Puerto Rico; Urbana, IL, USA) [41,42], and these publicly accessible data for our four NAM

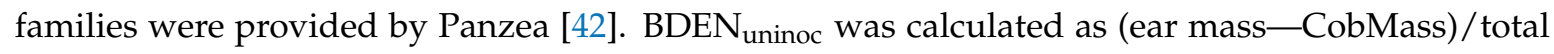
kernel volume. Assuming cob shape to be cylindrical, cob volume (CobVol) was calculated as $\pi^{*}$ CobLen*(CobDiam $\left./ 2\right)^{2}$. Cob density (CobDen) was calculated as CobMass/CobVol. To estimate genotype means for BDEN uninoc $_{\text {, }}$ CobDen, CobMass, and CobVol, we fit mixed linear models within and among families for these four ear traits with genotype and environment as random effects and DTS as a fixed effect using JMP ${ }^{\circledR}$ software (SAS Institute Inc., Cary, NC, USA, 1989-2007). Broad-sense heritability $(\mathrm{H})$ was calculated as

$$
\mathrm{H}=\frac{\sigma_{G}^{2}}{\sigma_{G}^{2}+\frac{\sigma_{\varepsilon}^{2}}{e}},
$$


where $e$ is the number of environments and $\sigma^{2}{ }_{\mathrm{G}}$ and $\sigma_{\varepsilon}^{2}$ are the genotype and error variances, respectively. Genotype means and broad-sense heritability for CobDiam and CobLen were accessed from Brown et al. [41].

\subsection{Trait Correlation Analyses}

Pairwise Pearson correlations among plot phenotypes and among trait best linear unbiased predictors (BLUPs) for quantitatively measured traits $\left(\mathrm{BDEN}_{\mathrm{inoc}}, \mathrm{BDEN}_{\text {uninoc }}, \mathrm{FER}, \mathrm{FUM}, \mathrm{FUM}: \mathrm{FER}\right)$ were calculated within families using JMP ${ }^{\circledR}$ software (SAS Institute Inc., Cary, NC, USA 1989-2007). Both plot-level (phenotypic) and BLUP (genetic) correlations were assessed among the FVI traits. Genetic correlations among BLUPs for $\mathrm{BDEN}_{\text {uninoc }}$ and FVI traits were also calculated.

\subsection{Comparison of Disease Severity among Families}

We tested differences in FVI severity among families using JMP ${ }^{\circledR}$ software (SAS Institute Inc., Cary, NC, USA, 1989-2007). We used analysis of variance (ANOVA) to test the effect of family on $\mathrm{BDEN}_{\text {inoc, }}$ FER, FUM, and FUM:FER, and pairwise two-tailed $t$-tests to asses differences in these four traits between families. A likelihood ratio $\chi^{2}$ test was used to compare the composition of symptom types among families.

\subsection{QTL Mapping, Colocalization, and Allele Effects}

The NAM population had been analyzed with genotyping-by-sequencing (GBS) technology [68]. A subset of 7386 GBS markers with $0.2 \mathrm{cM}$ resolution had been selected by Olukolu et al. [69]. We extracted the 7386 GBS markers for the B73 $\times$ CML333, B73 $\times$ CML52, B73 $\times$ CML69, and B73 $\times$ NC358 NAM families and used them for stepwise regression.

Stepwise regression models were fit in TASSEL version 5.2.37 [70] to identify markers associated with $\mathrm{BDEN}_{\text {inoc, }}, \mathrm{BDEN}_{\text {uninoc, }}$ FER, FUM, FUM:FER, and the five symptom types (asymptomatic, blush, starburst, purple, moldy). For the single-family models, a marker significance threshold of 0.001 was used [71]. For the joint-family models, marker effects were nested within family and the significance threshold was set to 0.0001 [71]. QTL were defined by the confidence intervals (CIs) of markers selected by stepwise regression [70]. Within each family, QTL were considered colocalized if their CIs overlapped.

In addition to identifying colocalized QTL, we also sought to investigate allele effect relationships at specific colocalized QTL. We extracted allele effect estimates from the TASSEL stepwise regression model outputs [70] and then compared allele effects on traits that had colocalized QTL.

\subsection{Characterization of Resistance QTL}

We classified the QTL mapped in our study as (1) FVI-specific if the trait-specific or colocalized QTL was only associated with FVI trait(s) or (2) FVI-ear colocalized if the QTL was associated with both ear and FVI trait(s). With JMP ${ }^{\circledR}$ software, we fit a linear model including absolute marker effect as the response and trait, family, resistance locus type, and QTL confidence interval size as fixed effects. We determined in which genetic bin(s) each resistance QTL was located using bin physical position (AGPv2) information from MaizeGDB [72], and if the QTL overlapped the bin containing the centromere on the respective chromosome, the QTL was classified as pericentromeric. We then compared the proportion of pericentromeric QTL between the two classes of resistance loci. We amassed loci associated with resistance to $F$. verticillioides from nine publications $[19,49,53-59]$ and determined which of our QTL overlapped with said previously described loci. 
Supplementary Materials: The following are available online at http:/ www.mdpi.com/2072-6651/11/2/86/s1, Table S1: Genotype-means correlations among kernel bulk density $\left(\mathrm{BDEN}_{\text {inoc }}\right)$, Fusarium ear rot (FER), fumonisin concentration (FUM), and the ratio of FUM to FER (FUM:FER) under F. verticillioides inoculation, and kernel bulk density (BDENuninoc) and cob density (CobDen), diameter (CobDiame), length (CobLen), mass (CobMass), and volume (CobVol) under uninoculated conditions within four maize RIL families.; Table S2: Summary of family-specific and joint family stepwise regression models and QTL for kernel bulk density (BDEN inoc ), Fusarium ear rot (FER), fumonisin concentration (FUM), and the ratio of FUM to FER (FUM:FER) under F. verticillioides inoculation, and kernel bulk density $\left(\mathrm{BDEN}_{\text {uninoc }}\right)$ and cob density (CobDen), diameter (CobDiam), length (CobLen), mass (CobMass), and volume (CobVol) under uninoculated conditions; Table S3: Physical positions (AGPv2) and associated traits of colocalized and trait-specific QTL from family-specific and joint family analyses.

Author Contributions: Conceptualization, L.M. and R.J.N.; Methodology, L.M., C.T.Z., P.J.B.-K., J.B.H. and R.J.N.; Formal Analysis, L.M.; Investigation, L.M., C.T.Z., D.E.M.M. and M.M.A.; Resources, P.J.B.-K., J.B.H. and R.J.N.; Data Curation, L.M.; Writing-Original Draft Preparation, L.M.; Writing-Review \& Editing, L.M., P.J.B.-K., J.B.H. and R.J.N.; Visualization, L.M.; Supervision, R.J.N.; Funding Acquisition, P.J.B.-K., J.B.H. and R.J.N.

Funding: This research was funded by National Science Foundation Plant Genome Research Program grant number 1127076 and McKnight Foundation project number 80267.

Acknowledgments: The authors wish to thank Jason Brewer and Judith Kolkman for technical support and Nicolas Morales for data management.

Conflicts of Interest: The authors declare no conflict of interest.

\section{References}

1. Rheeder, J.P.; Marasas, W.F.O.; Vismer, H.F. Production of Fumonisin Analogs by Fusarium Species. Appl. Environ. Microbiol. 2002, 68, 2101-2105. [CrossRef] [PubMed]

2. Mueller, D.S.; Wise, K.A.; Sisson, A.J.; Allen, T.W.; Bergstrom, G.C.; Bosley, D.B.; Bradley, C.A.; Broders, K.D.; Byamukama, E.; Chilvers, M.I.; et al. Corn Yield Loss Estimates Due to Diseases in the United States and Ontario, Canada from 2012 to 2015. Plant Health Prog. 2016, 17, 211-222. [CrossRef]

3. Wild, C.P.; Gong, Y.Y. Mycotoxins and Human Disease: A Largely Ignored Global Health Issue. Carcinogenesis 2009, 31, 71-82. [CrossRef] [PubMed]

4. Marasas, W.F.O.; Riley, R.T.; Hendricks, K.A.; Stevens, V.L.; Sadler, T.W.; Gelineau-van Waes, J.; Missmer, S.A.; Cabrera, J.; Torres, O.; Gelderblom, W.C.A.; et al. Fumonisins Disrupt Sphingolipid Metabolism, Folate Transport, and Neural Tube Development in Embryo Culture and in Vivo: A Potential Risk Factor for Human Neural Tube Defects among Populations Consuming Fumonisin-Contaminated Maize. J. Nutr. 2004, 134, 711-716. [CrossRef] [PubMed]

5. Missmer, S.A.; Suarez, L.; Felkner, M.; Wang, E.; Alfred, H.; Rothman, K.J.; Hendricks, K.A. Exposure to Fumonisins and the Occurrence of Neural Tube Defects along the Texas-Mexico Border. Environ. Health Perspect. 2006, 114, 237-241. [CrossRef] [PubMed]

6. Kimanya, M.E.; De Meulenaer, B.; Roberfroid, D.; Lachat, C. Fumonisin Exposure through Maize in Complementary Foods is Inversely Associated with Linear Growth of Infants in Tanzania. Mol. Nutr. Food Res. 2010, 54, 1659-1667. [CrossRef]

7. Kellerman, T.; Marasas, W.; Thiel, P.; Gelderblom, W.C.A.; Cawood, M.; Coetzer, J. Leukoencephalomalacia in Two Horses Induced by Oral Dosing of Fumonisin B ${ }_{1}$. Onderstepoort J. Vet. Res. 1990, 57, 269-275.

8. Colvin, B.M.; Harrison, L.R. Fumonisin-Induced Pulmonary Edema and Hydrothorax in Swine. Mycopathologia 1992, 117, 79-82. [CrossRef]

9. Mutiga, S.K.; Were, V.; Hoffmann, V.; Harvey, J.W.; Milgroom, M.G.; Nelson, R.J. Extent and Drivers of Mycotoxin Contamination: Inferences from a Survey of Kenyan Maize Mills. Phytopathology 2014, 104, 1221-1231. [CrossRef]

10. Bankole, S.A.; Mabekoje, O.O. Occurrence of Aflatoxins and Fumonisins in Preharvest Maize from South-Western Nigeria. Food Addit. Contam. 2004, 21, 251-255. [CrossRef]

11. Fandohan, P.; Gnonlonfin, B.; Hell, K.; Marasas, W.F.O.; Wingfield, M.J. Natural Occurrence of Fusarium and Subsequent Fumonisin Contamination in Preharvest and Stored Maize in Benin, West Africa. Int. J. Food Microbiol. 2005, 99, 173-183. [CrossRef] [PubMed]

12. Arino, A.; Herrera, M.; Juan, T.; Estopanan, G.; Carraminana, J.J.; Rota, C.; Herrera, A. Influence of Agricultural Practices on the Contamination of Maize by Fumonisin Mycotoxins. J. Food Prot. 2009, 72, 898-902. [CrossRef] [PubMed] 
13. Blandino, M.; Reyneri, A.; Vanara, F. Influence of Nitrogen Fertilization on Mycotoxin Contamination of Maize Kernels. Crop Prot. 2008, 27, 222-230. [CrossRef]

14. Lanubile, A.; Maschietto, V.; Borrelli, V.M.; Stagnati, L.; Logrieco, A.F.; Marocco, A. Molecular Basis of Resistance to Fusarium Ear Rot in Maize. Front. Plant Sci. 2017, 8, 1-13. [CrossRef]

15. Afolabi, C.G.; Bandyopadhyay, R.; Leslie, J.F.; Ekpo, E.J.A. Effect of Sorting on Incidence and Occurrence of Fumonisins and Fusarium verticillioides on Maize from Nigeria. J. Food Prot. 2006, 69, 2019-2023. [CrossRef]

16. Stasiewicz, M.J.; Falade, T.D.O.; Mutuma, M.; Mutiga, S.K.; Harvey, J.J.W.; Fox, G.; Pearson, T.C.; Muthomi, J.W.; Nelson, R.J. Multi-Spectral Kernel Sorting to Reduce Aflatoxins and Fumonisins in Kenyan Maize. Food Control 2017, 78, 203-214. [CrossRef]

17. Dombrink-Kurtzman, M.A.; Dvorak, T.J.; Barron, M.E.; Rooney, L.W. Effect of Nixtamalization (Alkaline Cooking) on Fumonisin-Contaminated Corn for Production of Masa and Tortillas. J. Agric. Food Chem. 2000, 48, 5781-5786. [CrossRef]

18. Humpf, H.-U.; Voss, K.A. Effects of Thermal Food Processing on the Chemical Structure and Toxicity of Fumonisin Mycotoxins. Mol. Nutr. Food Res. 2004, 48, 255-269. [CrossRef]

19. Robertson-Hoyt, L.A.; Jines, M.P.; Balint-Kurti, P.J.; Kleinschmidt, C.E.; White, D.G.; Payne, G.A.; Maragos, C.M.; Molna, T.L.; Holland, J.B. QTL Mapping for Fusarium Ear Rot and Fumonisin Contamination Resistance in Two Maize Populations. Crop Sci. 2006, 46, 1734-1743. [CrossRef]

20. Zila, C.T.; Ogut, F.; Romay, M.C.; Gardner, C.A.; Buckler, E.S.; Holland, J.B. Genome-Wide Association Study of Fusarium Ear Rot Disease in the U.S.A. Maize Inbred Line Collection. BMC Plant Biol. 2014, 14, 372. [CrossRef]

21. Zila, C.T.; Samayoa, L.F.; Santiago, R.; Butrón, A.; Holland, J.B. A Genome-Wide Association Study Reveals Genes Associated with Fusarium Ear Rot Resistance in a Maize Core Diversity Panel. G3 2013, 3, 2095-2104. [CrossRef] [PubMed]

22. Poland, J.A.; Balint-Kurti, P.J.; Wisser, R.J.; Pratt, R.C.; Nelson, R.J. Shades of Gray: The World of Quantitative Disease Resistance. Trends Plant Sci. 2009, 14, 21-29. [CrossRef] [PubMed]

23. Dall'Asta, C.; Giorni, P.; Cirlini, M.; Reverberi, M.; Gregori, R.; Ludovici, M.; Camera, E.; Fanelli, C.; Battilani, P.; Scala, V. Maize Lipids Play a Pivotal Role in the Fumonisin Accumulation. World Mycotoxin J. 2015, 8, 87-97. [CrossRef]

24. Lanubile, A.; Ferrarini, A.; Maschietto, V.; Delledonne, M.; Marocco, A.; Bellin, D. Functional Genomic Analysis of Constitutive and Inducible Defense Responses to Fusarium verticillioides Infection in Maize Genotypes with Contrasting Ear Rot Resistance. BMC Genom. 2014, 15, 710. [CrossRef] [PubMed]

25. Wang, Y.; Zhou, Z.; Gao, J.; Wu, Y.; Xia, Z.; Zhang, H.; Henry, R. The Mechanisms of Maize Resistance to Fusarium verticillioides by Comprehensive Analysis of RNA-Seq Data. Front. Plant Sci. 2016, 7, 1654. [CrossRef] [PubMed]

26. Sampietro, D.A.; Fauguel, C.M.; Vattuone, M.A.; Presello, D.A.; Catalán, C.A.N. Phenylpropanoids from Maize Pericarp: Resistance Factors to Kernel Infection and Fumonisin Accumulation by Fusarium verticillioides. Eur. J. Plant Pathol. 2013, 135, 105-113. [CrossRef]

27. Burr, S.; Fry, S. Feruloylated Arabinoxylans Are Oxidatively Cross-Linked by Extracellular Maize Peroxidase but Not by Horseradish Peroxidase. Mol. Plant 2009, 2, 883-892. [CrossRef]

28. Blandino, M.; Reyneri, A. Effect of Maize Hybrid Maturity and Grain Hardness on Fumonisin and Zearalenone Contamination. Ital. J. Agron. 2008, 2, 107-117. [CrossRef]

29. Sampietro, D.A.; Vattuone, M.A.; Presello, D.A.; Fauguel, C.M. The Pericarp and Its Surface Wax Layer in Maize Kernels as Resistance Factors to Fumonisin Accumulation by Fusarium verticillioides. Crop Prot. 2009, 28, 196-200. [CrossRef]

30. Bluhm, B.H.; Woloshuk, C.P. Amylopectin Induces Fumonisin B 1 Production by Fusarium verticillioides during Colonization of Maize Kernels. Mol. Plant-Microbe Interact. 2005, 18, 1333-1339. [CrossRef]

31. Mutiga, S.K.; Morales, L.; Angwenyi, S.; Wainaina, J.; Harvey, J.; Das, B.; Nelson, R.J. Association between Agronomic Traits and Aflatoxin Accumulation in Diverse Maize Lines Grown under Two Soil Nitrogen Levels in Eastern Kenya. Field Crop. Res. 2017, 205, 124-134. [CrossRef]

32. Shetty, P.H.; Bhat, R.V. A Physical Method for Segregation of Fumonisin-Contaminated Maize. Food Chem. 1999, 66, 371-374. [CrossRef] 
33. Morales, L.; Marino, T.P.; Wenndt, A.J.; Fouts, J.Q.; Holland, J.B.; Nelson, R.J. Dissecting Symptomatology and Fumonisin Contamination Produced by Fusarium verticillioides in Maize Ears. Phytopathology 2018, 108, 1475-1485. [CrossRef] [PubMed]

34. Marino, T.P. Genomic Prediction and QTL Validation for Resistance to Fusarium Ear Rot and Fumonisin in Maize. Ph.D. Thesis, North Carolina State University, Raleigh, NC, USA, October 2018.

35. Horne, D.W.; Eller, M.S.; Holland, J.B. Responses to Recurrent Index Selection for Reduced Fusarium Ear Rot and Lodging and for Increased Yield in Maize. Crop Sci. 2016, 56, 85-94. [CrossRef]

36. Jansen, C.; Zhang, Y.; Liu, H.; Gonzalez-Portilla, P.J.; Lauter, N.; Kumar, B.; Trucillo-Silva, I.; Martin, J.P.S.; Lee, M.; Simcox, K.; et al. Genetic and Agronomic Assessment of Cob Traits in Corn under Low and Normal Nitrogen Management Conditions. Theor. Appl. Genet. 2015, 128, 1231-1242. [CrossRef] [PubMed]

37. Parsons, M.W.; Munkvold, G.P. Effects of Planting Date and Environmental Factors on Fusarium Ear Rot Symptoms and Fumonisin $B_{1}$ Accumulation in Maize Grown in Six North American Locations. Plant Pathol. 2012, 61, 1130-1142. [CrossRef]

38. Parsons, M.W.; Munkvold, G.P. Associations of Planting Date, Drought Stress, and Insects with Fusarium Ear Rot and Fumonisin $B_{1}$ Contamination in California Maize. Food Addit. Contam. 2010, 27, 591-607. [CrossRef]

39. Desjardins, A.E.; Plattner, R.D.; Lu, M.; Claflin, L.W. Distribution of Fumonisins in Maize Ears Infected with Strains of Fusarium moniliforme That Differ in Fumonisin Production. Plant Dis. 1998, 82, 953-958. [CrossRef]

40. Yu, J.; Holland, J.B.; McMullen, M.D.; Buckler, E.S. Genetic Design and Statistical Power of Nested Association Mapping in Maize. Genetics 2008, 178, 539-551. [CrossRef]

41. Brown, P.J.; Upadyayula, N.; Mahone, G.S.; Tian, F.; Bradbury, P.J.; Myles, S.; Holland, J.B.; Flint-Garcia, S.; McMullen, M.D.; Buckler, E.S.; et al. Distinct Genetic Architectures for Male and Female Inflorescence Traits of Maize. PLoS Genet. 2011, 7, e1002383. [CrossRef]

42. Zhao, W. Panzea: A Database and Resource for Molecular and Functional Diversity in the Maize Genome. Nucleic Acids Res. 2006, 34, D752-D757. [CrossRef] [PubMed]

43. Robertson, L.A.; Kleinschmidt, C.E.; White, D.G.; Payne, G.A.; Maragos, C.M.; Holland, J.B. Heritabilities and Correlations of Fusarium Ear Rot Resistance and Fumonisin Contamination Resistance in Two Maize Populations. Crop Sci. 2006, 46, 353-361. [CrossRef]

44. Hung, H.Y.; Holland, J.B. Diallel Analysis of Resistance to Fusarium Ear Rot and Fumonisin Contamination in Maize. Crop Sci. 2012, 52, 2173-2181. [CrossRef]

45. Zummo, N.; Scott, G.E. Cob and Kernel Infection by Aspergillus flavus and Fusarium moniliforme in Inoculated, Field-Grown Maize Ears. Plant Dis. 1990, 74, 627-631. [CrossRef]

46. Presello, D.A.; Botta, G.; Iglesias, J.; Eyhérabide, G.H. Effect of Disease Severity on Yield and Grain Fumonisin Concentration of Maize Hybrids Inoculated with Fusarium verticillioides. Crop Prot. 2008, 27, 572-576. [CrossRef]

47. Presello, D.A.; Iglesias, J.; Botta, G.; Eyherabide, G.H. Severity of Fusarium Ear Rot and Concentration of Fumonisin in Grain of Argentinian Maize Hybrids. Crop Prot. 2007, 26, 852-855. [CrossRef]

48. Robertson-Hoyt, L.A.; Betrán, J.; Payne, G.A.; White, D.G.; Isakeit, T.; Maragos, C.M.; Molnár, T.L.; Holland, J.B. Relationships Among Resistances to Fusarium and Aspergillus Ear Rots and Contamination by Fumonisin and Aflatoxin in Maize. Phytopathology 2007, 97, 311-317. [CrossRef] [PubMed]

49. Mideros, S.X.; Warburton, M.L.; Jamann, T.M.; Windham, G.L.; Williams, W.P.; Nelson, R.J. Quantitative Trait Loci Influencing Mycotoxin Contamination of Maize: Analysis by Linkage Mapping, Characterization of Near-Isogenic Lines, and Meta-Analysis. Crop Sci. 2014, 54, 127. [CrossRef]

50. Fox, G.; Manley, M. Hardness Methods for Testing Maize Kernels. J. Agric. Food Chem. 2009, 57, 5647-5657. [CrossRef]

51. Kandianis, C.B.; Michenfelder, A.S.; Simmons, S.J.; Grusak, M.A.; Stapleton, A.E. Abiotic Stress Growth Conditions Induce Different Responses in Kernel Iron Concentration across Genotypically Distinct Maize Inbred Varieties. Front. Plant Sci. 2013, 4, 1-10. [CrossRef]

52. Rodgers-Melnick, E.; Bradbury, P.J.; Elshire, R.J.; Glaubitz, J.C.; Acharya, C.B.; Mitchell, S.E.; Li, C.; Li, Y.; Buckler, E.S. Recombination in Diverse Maize Is Stable, Predictable, and Associated with Genetic Load. Proc. Natl. Acad. Sci. USA 2015, 112, 201413864. [CrossRef] [PubMed]

53. Chen, J.; Shrestha, R.; Ding, J.; Zheng, H.; Mu, C.; Wu, J.; Mahuku, G. Genome-Wide Association Study and QTL Mapping Reveal Genomic Loci Associated with Fusarium Ear Rot Resistance in Tropical Maize Germplasm. G3 2016, 8651, g3-116. [CrossRef] [PubMed] 
54. Eller, M.S.; Payne, G.A.; Holland, J.B. Selection for Reduced Fusarium Ear Rot and Fumonisin Content in Advanced Backcross Maize Lines and Their Topcross Hybrids. Crop Sci. 2010, 50, 2249-2260. [CrossRef]

55. Ding, J.-Q.; Wang, X.-M.; Chander, S.; Yan, J.-B.; Li, J.-S. QTL Mapping of Resistance to Fusarium Ear Rot Using a RIL Population in Maize. Mol. Breed. 2008, 22, 395-403. [CrossRef]

56. Xiang, K.; Zhang, Z.M.; Reid, L.M.; Zhu, X.Y.; Yuan, G.S.; Pan, G.T. A Meta-Analysis of QTL Associated with Ear Rot Resistance in Maize. Maydica 2010, 55, 281-290.

57. Maschietto, V.; Colombi, C.; Pirona, R.; Pea, G.; Strozzi, F.; Marocco, A.; Rossini, L.; Lanubile, A. QTL Mapping and Candidate Genes for Resistance to Fusarium Ear Rot and Fumonisin Contamination in Maize. BMC Plant Biol. 2017, 17, 20. [CrossRef] [PubMed]

58. Giomi, G.M.; Kreff, E.D.; Iglesias, J.; Fauguel, C.M.; Fernandez, M.; Oviedo, M.S.; Presello, D.A. Quantitative Trait Loci for Fusarium and Gibberella Ear Rot Resistance in Argentinian Maize Germplasm. Euphytica 2016, 211, 287-294. [CrossRef]

59. Perez-Brito, D.; Jeffers, D.; Gonzalez-de-Leon, D.; Khairallah, M.; Cortes-Cruz, M.; Velazquez-Cardelas, G.; Azpiroz-Rivero, S.; Srinivasan, G. QTL Mapping of Fusarium moniliforme Ear Rot Resistance in High Land Maize, Mexico. Agrociencia 2001, 35, 181-196.

60. Clements, M.J.; Kleinschmidt, C.E.; Maragos, C.M.; Pataky, J.K.; White, D.G. Evaluation of Inoculation Techniques for Fusarium Ear Rot and Fumonisin Contamination of Corn. Plant Dis. 2003, 87, 147-153. [CrossRef]

61. Gustin, J.L.; Jackson, S.; Williams, C.; Patel, A.; Armstrong, P.; Peter, G.F.; Settles, A.M. Analysis of Maize (Zea mays) Kernel Density and Volume Using Microcomputed Tomography and Single-Kernel Near-Infrared Spectroscopy. J. Agric. Food Chem. 2013, 61, 10872-10880. [CrossRef]

62. Shelby, R.A.; White, D.G.; Bauske, E.M. Differential Fumonisin Production in Maize Hybrids. Plant Dis. 1994, 78, 582-584. [CrossRef]

63. Buckler, E.S.; Holland, J.B.; Bradbury, P.J.; Acharya, C.B.; Brown, P.J.; Browne, C.; Ersoz, E.; Flint-Garcia, S.; Garcia, A.; Glaubitz, J.C.; et al. The Genetic Architecture of Maize Flowering Time. Science 2009, 325, 714-718. [CrossRef] [PubMed]

64. Costa, R.S.; Môro, F.V.; Môro, J.R.; da Silva, H.P.; Panizzi, R.D.C. Relação Entre Características Morfológicas Da Cariopse e Fusariose Em Milho. Pesqui. Agropecu. Bras. 2003, 38, 27-33. [CrossRef]

65. Duncan, K.E.; Howard, R.J. Biology of Maize Kernel Infection by Fusarium verticillioides. Mol. Plant-Microbe Interact. 2010, 23, 6-16. [CrossRef] [PubMed]

66. Owens, B.; Lipka, A.; Magallanes-Lundback, M.; Tiede, T.; Diepenbrock, C.; Kandianis, C.B.; Kim, E.; Cepela, J.; Mateos-Hernandez, M.; Buell, C.; et al. A Foundation for Provitamin A Biofortification of Maize: Genome-Wide Association and Genomic Prediction Models of Carotenoid Levels. Genetics 2014, 198, 1699-1716. [CrossRef] [PubMed]

67. Holland, J.B.; Nyquist, W.E.; Cervantes-Martinez, C.T. Estimating and Interpreting Heritability for Plant Breeding. Plant Breed. Rev. 2003, 22, 9-112.

68. Elshire, R.J.; Glaubitz, J.C.; Sun, Q.; Poland, J.A.; Kawamoto, K.; Buckler, E.S.; Mitchell, S.E. A Robust, Simple Genotyping-by-Sequencing (GBS) Approach for High Diversity Species. PLoS ONE 2011, 6, e19379. [CrossRef]

69. Olukolu, B.A.; Wang, G.F.; Vontimitta, V.; Venkata, B.P.; Marla, S.; Ji, J.; Gachomo, E.; Chu, K.; Negeri, A.; Benson, J.; et al. A Genome-Wide Association Study of the Maize Hypersensitive Defense Response Identifies Genes That Cluster in Related Pathways. PLoS Genet. 2014, 10, e1004562. [CrossRef]

70. Bradbury, P.J.; Zhang, Z.; Kroon, D.E.; Casstevens, T.M.; Ramdoss, Y.; Buckler, E.S. TASSEL: Software for Association Mapping of Complex Traits in Diverse Samples. Bioinformatics 2007, 23, 2633-2635. [CrossRef]

71. Peiffer, J.A.; Romay, M.C.; Gore, M.A.; Flint-Garcia, S.A.; Zhang, Z.; Millard, M.J.; Gardner, C.A.C.; McMullen, M.D.; Holland, J.B.; Bradbury, P.J.; et al. The Genetic Architecture of Maize Height. Genetics 2014, 196, 1337-1356. [CrossRef]

72. Andorf, C.M.; Cannon, E.K.; Portwood, J.L.; Gardiner, J.M.; Harper, L.C.; Schaeffer, M.L.; Braun, B.L.; Campbell, D.A.; Vinnakota, A.G.; Sribalusu, V.V.; et al. MaizeGDB Update: New Tools, Data and Interface for the Maize Model Organism Database. Nucleic Acids Res. 2016, 44, D1195-D1201. [CrossRef] [PubMed] 